\title{
Methanolic Extract of Musa Sapientum Surker Proffers Antioxidant Effects against Indomethacin-Induced Ulceration Oxidative stress in Wistar Rats
}

\author{
${ }^{1 *}$ Salau B. A, ${ }^{1}$ Adeosun C. B, ${ }^{2}$ Odufuwa K. T, ${ }^{3}$ Kale O E, ${ }^{1}$ Olukanni O. D, ${ }^{2}$ Adeyanju M. M. \\ ${ }^{I}$ Department of Chemical Sciences, College of Natural Science, Redeemer's University, Km 46, Lagos/Ibadan \\ Expressway, PMB 3005, Redemption City Mowe, Ogun State, Nigeria \\ ${ }^{2}$ Department of Biochemistry, Obafemi Awolowo College of Health Sciences, Ikenne Campus, Olabisi Onabanjo \\ University, Ago-Iwoye, Ogun State. \\ ${ }^{3}$ Department of Chemical Pharmacology, ObafemiAwolowo College of Health Sciences, Ikenne Campus, \\ OlabisiOnabanjo University, Ago-Iwoye, Ogun State.
}

\begin{abstract}
Effect of methanolic extract of musa sapientum sucker (MEMSS) in indomethacin-induced ulceration in Wistar rats was investigated. Thirty albino rats (120-150 g) were divided into six groups. Negative and positive control rats (group 1 and 2) received no treatment and indomethacin $(50 \mathrm{mg} / \mathrm{kg}$ ) respectively. Group 3 rats received Omeprazole $(0.8 \mathrm{mg} / \mathrm{kg}) 4$ hours following indomethacin $(50 \mathrm{mg} / \mathrm{kg})$ intoxication. Groups 4, 5, and 6 received $5 \mathrm{mg} / \mathrm{kg}, 10 \mathrm{mg} / \mathrm{kg}$ and $20 \mathrm{mg} / \mathrm{kg}$ of MEMSS respectively 4 hour after indomethacin $(50 \mathrm{mg} / \mathrm{kg}$ ) induction. Treatment last for fourteen days and dosing was via oral route. Rats were anaesthetized and sacrificed 24 hours following last treatment. In our results, we scored ulcer induction by indomethacin using elevated biomarker enzymes. Indomethacin $(50 \mathrm{mg} / \mathrm{kg})$ administered alone increased $(p<0.05)$ hepatic and renal alanine and aspartate aminotransferases ${ }_{L} A L T,{ }_{L} A S T$ and $\left.{ }_{K} A L T,{ }_{K} A S T\right)$ by $311.2 \%, 170.8 \%$ and $123.7 \%$, $109.7 \%$ respectively when compared with negative control group. Similarly, MEMSS significantly reduced the elevated ${ }_{L} A L T,{ }_{L} A S T$ and ${ }_{K} A L T,{ }_{K} A S T$ quantitatively when compared with positive control (IDM) group. MEMSS when administered at graded doses $(5,10$ and $20 \mathrm{mg} / \mathrm{kg})$ increased $(p<0.05)$ catalase levels, liver and kidney SOD levels $(p<0.05)$ when compared with control groups. $20 \mathrm{mg} / \mathrm{kg}$ of MEMSS increased liver and renal reduced glutathione by $69.6 \%$ and $32.7 \%$ respectively. In conclusion, MEMSS possesses antioxidant benefits against indomethacin-induced ulceration and oxidative stress in rats which could attracts further histomorphological studies.
\end{abstract}

Key words: Musa sapientum sucker, Indomethacin, Ulceration, Antioxidants

\section{Introduction}

The exploration of biologically active natural products have played an important role in finding new chemical entities which has significantly contributed to the development of different traditional systems of medicine. This has extended to the discovery of different medicinal plants to find the scientific basis of their traditional uses (Newman et al., 2003; Jachak and Saklani, 2007). Although, challenges and opportunities in drug discovery from plants remain to be resolved, banana has been used in folk medicine to treat peptic ulcer disease. Studies to show its gastroprotective effect of the ethanolic extracts of both M. sapientum and M. paradisiaca has been demonstrated (Jain et al., 2007). The use of M. sapientum in peptic ulcer as a component of herbal medicine has been evaluated and found effective (Goel and Sairam, 2002). It has also shown that the fruit peel ash of M. sapientum possesses acid neutralizing capacity and produced an increase in urine volume and $\mathrm{K}^{+}$ as well as other electrolyte excretion than normal saline in a study in rats. More so, an ethanolic extract of the same generated a diuretic effect (Jain et al., 2007). Evidence abounds in both folk medicine and experimental theories in the ability of banana and plantain to possibly reduce oxidative stress in vivo (Jain et al., 2007; Yin et al., 2008; Salau et al., 2010). A study illustrated significant reduction in oxidative stress after a single banana meal in healthy human due to its antioxidant activity (Yin et al., 2008). Moreso, characteristics of banana in wound healing activity and lowering blood glucose in rats, inhibition of dehydrogenase activity in pathogenic bacteria; isolates leading to identification of natural flavonoids as well as prevention of plasma oxidative stress in healthy individuals is a plausibility of its antioxidant capacity (Lewis et al., 1999; Alisi et al., 2008; Agarwal et al., 2009; Salau et al., 2010). Several antioxidant substances such as flavonoids, dopamine, ascorbic acid etc. have been identified in different parts of banana together with others in the form of glycosides, monosaccharide (Mokbel and Hashinaga, 2005; Vijayakumar et al., 2008). Interestingly, M. sapientum also possesses antidiabetic, antidiarrhoeal, antidysentery and antihemorrhagic activities. (Pari and Maheshwari, 2000; Albuquerque et al., 2007; Agarwal et al., 2009; Adewoye et al, 2009). This recent importance attributed to $M$. sapientum has gained the interest of scientists to investigate the medicinal importance of its different parts including its suckers. Recently, in our laboratory, we demonstrated lipid moderating effect and antidiabetic 
activity of methanolic extract of Musa Sapientum sucker in rats (Salau et al., 2010; Salau et al., 2012). In this present study, we investigated on the antioxidant effects of M. sapientum sucker in indomethacin-induced rats.

\section{Materials and methods}

\section{Chemicals and drugs}

Indomethacin $(25 \mathrm{mg}$ ) and Omeprazole (20 mg) were products of Taj Pharmaceuticals Ltd. 434, Laxmi Plaza, Laxmi Industrial Estate, New Link Road, Andheri (W), Mumbai (India). Reduced glutathione (GSH). Alanine aminotransferase (ALT), aspartate aminotransferase (AST), alkaline phosphatase (ALP) assay kits were obtained from Randox Laboratory (Crumlin, UK), 5',5'-dithiobis-2-nitrobenzoate (Ellman's reagent) from Sigma (USA) and sodium hydroxide from Merck (Germany), Spectrophotometer (Jenway Model 6405, UV/visible). All other chemicals and reagents used were of analytical grade.

\section{Plant Materials and Preparation of Extracts}

Some fresh Musa sapientum suckers were collected at around 3:30 pm some few miles away from the College of Health Sciences, Olabisi Onabanjo University, Sagamu, Ogun state, Nigeria. The identification and authenticity of the plant was done at the Forestry Research Institute, Ibadan, Nigeria. The suckers were dried and macerated. Sucker of musa sapientum (200g) of the pulverized sucker was soaked in $70 \%$ methanol for forty-eight (48) hours, the extract was filtered and then concentrated with rotary evaporator at the National Institute for Medical Research (NIMR). The dried product was kept in air tight dark container and the required dose was reconstituted in daily basis and administered.

\section{Experimental Design}

Thirty (30) white albino rats weighting 120-150 g were obtained from Obafemi Awolowo University, Ile Ife, Osun state Nigeria and were divided into six (6) groups. Animals were fed before and during the experiment with rat chow purchased from Ladoke feed, Challenge, Ibadan, Oyo state and were housed within the experimental animal handling facility of the department of Biochemistry, Olabisi Onabanjo University, Ogun State, Nigeria at ambient temperature and humidity with a $12 \mathrm{~h} \mathrm{light} / 12 \mathrm{~h}$ dark schedule. The rats were acclimatized for a period of one week before the commencement of treatments. Animals were provided with water ad libitum during period of acclimatization and throughout the period of the experiment. Study was carried out in strict compliance with established guidelines for care and use of laboratory animals in biomedical research.

Negative control rats in group 1 received no treatment. Animals in group 2 were treated with indomethacin $(50 \mathrm{mg} / \mathrm{kg})$ and served as the positive control. Rats in groups 3 were treated with omeprazole $(0.8$ $\mathrm{mg} / \mathrm{kg}$ ) four (4) hours following indomethacin $(50 \mathrm{mg} / \mathrm{kg})$ induction of ulcers. Groups 4, 5, and 6 received methanolic extract of musa sapietum sucker (MEMSS) $5 \mathrm{mg} / \mathrm{kg}, 10 \mathrm{mg} / \mathrm{kg}$ and $20 \mathrm{mg} / \mathrm{kg}$ four (4) hour after indomethacin $(50 \mathrm{mg} / \mathrm{kg})$ intoxication respectively. Omeprazole was administered at the therapeutic dosage. Treatment last for fourteen (14) days and dosing was via oral route. Rats were anaesthetized and killed 24 hours after the last treatment.

\section{Group Divisions:}

Group 1: Control negative group

Group 2: Indomethacin (IDM) $(50 \mathrm{mg} / \mathrm{kg})$

Group 3: Indomethacin $(50 \mathrm{mg} / \mathrm{kg})+$ OMP $(0.8 \mathrm{mg} / \mathrm{kg})$;

Group 4: Indomethacin $(50 \mathrm{mg} / \mathrm{kg})+$ methanolic extract of musa sapietum sucker (MEMSS) $(5 \mathrm{mg} / \mathrm{kg}$ );

Group 5: Indomethacin $(50 \mathrm{mg} / \mathrm{kg})+$ methanolic extract of musa sapietum sucker (MEMSS) $(10 \mathrm{mg} / \mathrm{kg})$;

Group 6: Indomethacin $(50 \mathrm{mg} / \mathrm{kg})+$ methanolic extract of musa sapietum sucker (MEMSS) $(20 \mathrm{mg} / \mathrm{kg})$;

\section{Animal Sacrifice}

All animals were sacrificed by diethlyether anasthesis, 24 hours following the last treatment and blood collected by cardiac puncture into lithium heparin bottles and centrifuged at $4200 \mathrm{rpm}$ at room temperature for 5 minutes to separate plasma. The kidney was carefully excised, cleared of adhering tissues, and weighed. The weight was recorded in grams and expressed as $\mathrm{g} / \mathrm{kg}$ body weight. The excised kidney was weighed and homogenized in four volumes of $100 \mathrm{mM}$ phosphate buffer ( $\mathrm{pH}$ 7.4). All the proceedings were carried out at a temperature not exceeding $4^{\circ} \mathrm{C}$. The plasma and kidney homogenate obtained from each animal were then analyzed to assess kidney antioxidants levels and other biochemical parameters. The liver, kidney and stomach was removed, cleared of adhering tissues and weighed. The organs were weighed and homogenized in four volumes of phosphate buffer (0.1 M, pH 7.4). Both serum and organs homogenate were used for biochemical analysis. 


\section{Biochemical Analysis}

Liver function was assessed by measuring the activities of AST, ALT, in liver and renal respectively. AST and ALT activities were determined according to the principle described by Reitman and Frankel (1957). GSH level was estimated at 412nm following the method of Beutler et al. (1963). Catalase activity was determined according to the methods of Sinha (1972). Superoxide dismutase (SOD) activity was determined by the method of Misra and Fridovich (1972).

\section{Statistical Analysis}

Differences between groups were determined by one-way analysis of variance (ANOVA), and post hoc testing was performed for intergroup comparisons using the least significant difference (LSD) (Levine, 1991). Data presented are mean \pm standard error of mean (SEM) and were analyzed using Statistical Package for Social Sciences (SPSS) software for windows. $\mathrm{P}<0.05$ was considered significant.

\section{Results}

Table 1: Effects of Methanolic Extract of Musa Sapentium on hepatic ( $\left.{ }_{L} A L T,{ }_{L} A S T\right)$ and renal $\left({ }_{k} A L T,{ }_{k} A S T\right)$ alanine and aspartate aminotransferases in rats.

\begin{tabular}{|c|c|c|c|c|}
\hline TREATMENTS & LALT (IU/g) & ${ }_{\text {LAST }}$ (IU/g) & ${ }_{k}$ ALT (IU/g) & kAST (IU/g) \\
\hline CONTROL & $10.7 \pm 1.0$ & $32.5 \pm 2.5$ & $15.2 \pm 1.1$ & $32.0 \pm 2.8$ \\
\hline IDM (50mg/kg) & $44.0 \pm 5.2^{\mathrm{a}}$ & $88.0 \pm 0.4^{\mathrm{a}}$ & $34.0 \pm 1.3^{\mathrm{a}}$ & $67.1 \pm 3.2^{\mathrm{a}}$ \\
\hline $\begin{array}{l}\text { IDM+OMP(50mg/kg) + } \\
(0.8 \mathrm{mg} / \mathrm{kg})\end{array}$ & $22.4 \pm 1.5^{\mathrm{a}, \mathrm{b}}$ & $64.6 \pm 8.8^{\mathrm{a}}$ & $20.7 \pm 5.4$ & $29.8 \pm 1.5^{\mathrm{b}}$ \\
\hline $\begin{array}{l}\text { DM + MEMSS } \\
(50 \mathrm{mg} / \mathrm{kg})(5 \mathrm{mg} / \mathrm{kg})\end{array}$ & $24.1 \pm 2.4^{\mathrm{a}, \mathrm{b}}$ & $63.6 \pm 6.4^{\mathrm{a}, \mathrm{b}}$ & $16.6 \pm 1.0^{\mathrm{b}}$ & $29.2 \pm 1.6^{\mathrm{b}}$ \\
\hline $\begin{array}{l}\text { IDM+MEMSS } \\
(50 \mathrm{mg} / \mathrm{kg})(10 \mathrm{mg} / \mathrm{kg})\end{array}$ & $15.3 \pm 1.1^{\mathrm{a}, \mathrm{b}}$ & $46.8 \pm 6.0^{\mathrm{a}, \mathrm{b}}$ & $11.9 \pm 0.9^{\mathrm{b}}$ & $29.8 \pm 1.5^{\mathrm{b}}$ \\
\hline $\begin{array}{l}\text { DM + MEMSS } \\
(50 \mathrm{mg} / \mathrm{kg})(20 \mathrm{mg} / \mathrm{kg})\end{array}$ & $10.8 \pm 1.0^{\mathrm{b}}$ & $28.8 \pm 0.6^{\mathrm{ab}}$ & $12.1 \pm 0.6^{\mathrm{b}}$ & $20.0 \pm 2.6^{\mathrm{b}}$ \\
\hline
\end{tabular}

Results represented as Mean \pm Standard error of mean. ${ }^{a} \mathrm{p}<0.05$ when compared with Control group (negative). ${ }^{b} \mathrm{p}<0.05$ when compared with IDM group (positive). IDM $=$ Indomethacin, OMP $=$ Omeprazole, ${ }_{\mathrm{L}} \mathrm{ALT}=\mathrm{Liver}$ Alanine Aminotransferase; ${ }_{\mathrm{L}} \mathrm{AST}=$ Liver Aspartate Aminotransferase; ${ }_{\mathrm{k}} \mathrm{ALT}=$ Kidney Alanine Aminotransferase; ${ }_{k} \mathrm{AST}=$ Kidney Alanine Aminotransferase.

In table1: Indomethacin $(50 \mathrm{mg} / \mathrm{kg})$ administered alone significantly $(\mathrm{p}<0.05)$ increased hepatic and renal alanine and aspartate aminotransferases ( ${ }_{L} \mathrm{ALT},{ }_{\mathrm{L}} \mathrm{AST}$ and ${ }_{\mathrm{K}} \mathrm{ALT},{ }_{\mathrm{K}} \mathrm{AST}$ ) by $311.2 \%, 170.8 \%$ and $123.7 \%$, $109.7 \%$ respectively when compared with negative control group. Also, indomethacin-induced $(50 \mathrm{mg} / \mathrm{kg}) \mathrm{group}$ when treated with omeprazole $(0.8 \mathrm{mg} / \mathrm{kg})$, reduced significantly $(\mathrm{p}<0.05)_{\mathrm{L}}$ ALT and ${ }_{\mathrm{L}}$ AST by $49.1 \%$ and $26.6 \%$ when compared with positive control (IDM) group. ${ }_{\mathrm{K}}$ ALT reduced insignificantly ( $\mathrm{p}>0.05$ ) by $39.1 \%$ while there was significant $(\mathrm{p}<0.05)_{\mathrm{K}}$ AST increased by $55.6 \%$. Interestingly, methanolic extract of musa sapientum sucker (MEMSS) significantly reduced the elevated ${ }_{\mathrm{L}} \mathrm{ALT},{ }_{\mathrm{L}} \mathrm{AST}$ and ${ }_{\mathrm{K}} \mathrm{ALT},{ }_{\mathrm{K}} \mathrm{AST}$ with increase dosing of $5 \mathrm{mg} / \mathrm{kg}$ (hepatic: $45.2 \%, 27.7 \%$; renal: $51.2 \%, 56.5 \%$ ); $10 \mathrm{mg} / \mathrm{kg}$ (hepatic: $65.2 \%, 46.8 \%$; renal: $65.0 \%, 55.6 \%$ ) and $20 \mathrm{mg} / \mathrm{kg}$ (hepatic: $75.5 \%, 67.3 \%$; renal: $64.4 \%, 70.2 \%$ ) respectively.

In table 2: Effects of Methanolic Extract of Musa Sapentium on stomach reduced glutathione ( $\left.{ }_{\mathrm{s}} \mathrm{GSH}\right)$, stomach superoxide dismutase ( $\left.{ }_{\mathrm{s}} \mathrm{SOD}\right)$, stomach catalase ( $\left.{ }_{\mathrm{S}} \mathrm{CAT}\right)$ in rats.

\begin{tabular}{|c|c|c|}
\hline TREATMENTS & ${ }_{\mathrm{S}}$ GSH & ${ }_{\mathrm{S}} \mathrm{CAT}$ \\
\hline CONTROL & $6.30 \pm 0.6$ & $3.48 \pm 0.2$ \\
\hline IDM (50mg/kg) & $5.58 \pm 0.1$ & $6.23 \pm 0.1$ \\
\hline $\begin{array}{l}\text { IDM+OMP(50mg/kg) + } \\
(0.8 \mathrm{mg} / \mathrm{kg})\end{array}$ & $7.65 \pm 0.3$ & $2.42 \pm 0.3^{b}$ \\
\hline $\begin{array}{l}\text { DM + MEMSS } \\
(50 \mathrm{mg} / \mathrm{kg})(5 \mathrm{mg} / \mathrm{kg}) \\
\end{array}$ & $7.68 \pm 0.3$ & $3.71 \pm 0.5$ \\
\hline $\begin{array}{l}\text { IDM+MEMSS } \\
(50 \mathrm{mg} / \mathrm{kg})(10 \mathrm{mg} / \mathrm{kg})\end{array}$ & $7.77 \pm 0.3$ & $2.02 \pm 0.2^{b}$ \\
\hline $\begin{array}{l}\text { DM + MEMSS } \\
(50 \mathrm{mg} / \mathrm{kg})(20 \mathrm{mg} / \mathrm{kg})\end{array}$ & $13.85 \pm 0.4^{b}$ & $1.45 \pm 0.9^{\mathrm{b}}$ \\
\hline
\end{tabular}

Results represented as Mean \pm Standard error of mean. ${ }^{a} \mathrm{p}<0.05$ when compared with Control group (negative). ${ }^{b} p<0.05$ when compared with IDM group (positive). ${ }^{c} p<0.001$ when compared with IDM group (positive). $\mathrm{IDM}=$ Indomethacin, $\mathrm{OMP}=$ Omeprazole, ${ }_{\mathrm{S}} \mathrm{GSH}=$ stomach reduced glutathione; ${ }_{\mathrm{S}} \mathrm{SOD}=$ stomach superoxide dismuase; ${ }_{\mathrm{S}} \mathrm{CAT}=$ stomach catalase. 
In table 2: Indomethacin $(50 \mathrm{mg} / \mathrm{kg})$ when given alone did not significantly ( $>>0.05)$ alter stomach reduced glutathione (GSH), catalase (CAT), but did increased superoxide dismutase (SOD) significantly by $113.6 \%$ when compared with negative control group. Also, indomethacin-induced rats when administered with omeprazole did not reduced stomach GSH, SOD, but did increased CAT significantly $(\mathrm{p}<0.05)$ by $61.2 \%$. Although, MEMSS when administered at graded doses of 5,10 and $20 \mathrm{mg} / \mathrm{kg}$ following indomethacin $(50 \mathrm{mg} / \mathrm{kg})$ intoxication did not significantly $(\mathrm{p}>0.05)$ increase stomach $\mathrm{GSH}$, however, catalase level was significantly increased $(\mathrm{p}<0.05)$ in all animals by $40.4 \%(5 \mathrm{mg} / \mathrm{kg}), 67.6 \%(10 \mathrm{mg} / \mathrm{kg}), 76.7 \%(20 \mathrm{mg} / \mathrm{kg})$ respectively when compared with positive control IDM group.

In table 3: Effects of Methanolic Extract of Musa Sapentium on liver reduced glutathione $\left.{ }_{\mathrm{L}} \mathrm{GSH}\right)$ and superoxide dismutase ( $\left.{ }_{\mathrm{L}} \mathrm{SOD}\right)$ and kidney reduced glutathione $\left({ }_{\mathrm{K}} \mathrm{GSH}\right)$ and superoxide dismutase $\left.{ }_{\mathrm{K}} \mathrm{SOD}\right)$ in rats.

\begin{tabular}{lllll}
\hline \multirow{2}{*}{ TREATMENTS } & \multicolumn{2}{c}{ LIVER } & \multicolumn{2}{c}{ KIDNEY } \\
\cline { 2 - 5 } & ${ }_{\mathbf{L}}$ GSH & ${ }_{\mathbf{L}}$ SOD & ${ }_{\mathbf{K}}$ GSH & ${ }_{\mathbf{K}}$ SOD \\
\hline CONTROL & $5.4 \pm 0.1$ & $253.3 \pm 8.5$ & $5.8 \pm 0.5$ & $164.3 \pm 1.1$ \\
\hline IDM (50mg/kg) & $4.4 \pm 0.2$ & $718.9 \pm 14.6^{\mathrm{a}}$ & $5.7 \pm 0.8$ & $184.0 \pm 1.2$ \\
\hline $\begin{array}{l}\text { IDM+OMP(50mg/kg) } \\
+\mathbf{( 0 . 8 m g / k g )}\end{array}$ & $5.6 \pm 0.2$ & $255.0 \pm 11.0^{\mathrm{b}}$ & $6.0 \pm 0.9$ & $160.2 \pm 0.2$ \\
\hline $\begin{array}{l}\text { DM + MEMSS } \\
\mathbf{5 0} \mathbf{m g} / \mathbf{k g})(\mathbf{5 m g} / \mathbf{k g})\end{array}$ & $5.9 \pm 0.2$ & $250.7 \pm 15.3^{\mathrm{b}}$ & $6.2 \pm 0.1$ & $160.5 \pm 0.7$ \\
\hline $\begin{array}{l}\text { IDM+MEMSS } \\
\mathbf{( 5 0 m g / k g ) ~ ( 1 0 m g / k g ) ~}\end{array}$ & $7.2 \pm 0.2$ & $213.8 \pm 14.5^{\mathrm{b}}$ & $7.4 \pm 0.2$ & $146.3 \pm 2.2$ \\
\hline $\begin{array}{l}\text { DM + MEMSS } \\
\mathbf{5 0} \mathbf{m g} / \mathbf{k g})(\mathbf{2 0} \mathbf{m g} / \mathbf{k g})\end{array}$ & $8.2 \pm 0.1^{\mathrm{b}}$ & $218.3 \pm 1.7^{\mathrm{b}}$ & $8.1 \pm 0.8$ & $123.8 \pm 2.2^{\mathrm{b}}$ \\
\hline
\end{tabular}

Results represented as Mean \pm Standard error of mean. ( $\mathrm{p}<0.05$ ) when compared with Control group (negative). $(\mathrm{p}<0.05)$ when compared with IDM group (positive control). IDM = Indomethacin, OMP = Omeprazole, ${ }_{L} \mathrm{GSH}$ $=$ stomach reduced glutathione; ${ }_{\mathrm{L}} \mathrm{GSH}=$ stomach reduced glutathione ${ }_{\mathrm{L}} \mathrm{SOD}=$ stomach superoxide dismuase; ${ }_{\mathrm{K}} \mathrm{SOD}=$ stomach superoxide.

In table 3: Indomethacin $(50 \mathrm{mg} / \mathrm{kg}$ ) when administered alone did not significantly ( $>>0.05)$ alter liver and kidney reduced glutathione ${ }_{\mathrm{L}} \mathrm{GSH}$ and $\left.{ }_{\mathrm{K}} \mathrm{GSH}\right)$ as well as kidney superoxide dismutase ${ }_{\mathrm{K}} \mathrm{SOD}$ ), but, it significantly increased $(\mathrm{p}<0.05)$ liver superoxide dismutase $\left.{ }_{\mathrm{L}} \mathrm{SOD}\right)$ by $183.8 \%$ when compared with negative control group. Similarly, ${ }_{\mathrm{L}} \mathrm{GSH},{ }_{\mathrm{K}} \mathrm{GSH}$ in indomethacin-induced rats when treated with omeprazole were not significantly $(p>0.05)$ altered whereas ${ }_{L}$ SOD increased $(p<0.05)$ by $64.5 \%$ when compared with positive control (IDM) group. In the MEMSS treated rats, when $5 \mathrm{mg} / \mathrm{kg}$ was administered, ${ }_{\mathrm{L}} \mathrm{GSH}$ and ${ }_{\mathrm{K}} \mathrm{GSH}$ were reduced insignificantly ( $p>0.05$ ) by $34.1 \%$ and $8.7 \%$ respectively when compared with positive control (IDM) group. Also, ${ }_{\mathrm{L}} \mathrm{SOD}$ significantly increased $(\mathrm{p}<0.05)$ by $65.1 \%$. ${ }_{\mathrm{K}} \mathrm{SOD}$ was reduced by $12.8 \%$. Given $10 \mathrm{mg} / \mathrm{kg}$ MEMSS, ${ }_{2}$ GSH and ${ }_{\mathrm{K}} \mathrm{GSH}$ declined by $63.6 \%$ and 29.8 respectively while increasing correspondingly their ${ }_{\mathrm{L}} \mathrm{SOD}$ and ${ }_{\mathrm{K}}$ SOD by $70.3 \%$ and $20.5 \%$ when compared with positive control (IDM) group. Similarly, $20 \mathrm{mg} / \mathrm{kg}$ MEMSS increased ${ }_{\mathrm{L}} \mathrm{GSH}$ and ${ }_{\mathrm{K}} \mathrm{GSH}$ by $69.6 \%$ and $32.7 \%$.

\section{Discussion}

Challenges and opportunities in drug discovery from plants are frequently transformed into medicine to treat different diseases in different areas of the world (Jachak and Saklani, 2007). Studies to show that NSAIDs caused inflammation, neutrophil infiltration as well as the possible role of oxidative free radicals and lipid peroxidation in mediating NSAID induced gastric injury in albino rats leading to free drug-induced gastric injury are available in animals and man (Narita et al., 2006; Adewoye et al, 2009). It was since reported that banana pulp powder (M. sapientum var. paradisiaca) showed significant anti-ulcerogenic activity in gastric ulcers, cysteamine- and histamine-induced duodenal ulcers in rats and guinea-pigs (Goel et al., 1986). Since, researchers have developed interest in the search of free radicals and oxidative stress scavengers in plants and herbs (Cochran et al., 1983; Kumaraguruparan et al., 2002). Oxidative free radicals help to maintain redox system and enhance tissue damage. Oxidative stress however results from an imbalance between oxidative free radicals formation and scavenging actions by antioxidants. And, it may be a common pathway linking diverse mechanisms for the pathogenesis of complications in gastric pathogenesis. Superoxide dismutase activity and reduced glutathione levels have been reported to decrease in various organs of diabetic animals, such as kidney, intestine and stomach (Tashima et al., 2000). This results in alterations in gastroduodenal motility which results in delayed gastric emptying and mucosal ulceration. Indomethacin is one of the traditional NSAIDs implicated to causing gastric muscle hypercontractility which interferes with the motor function of the stomach and 
contributes to the development of mucosal injury (Takeuchi et al., 2004; Narita et al., 2006). We first explored and recently reported antidiabetic importance of methanolic extract of musa sapientum surcker following detailed phytochemical screening (Salau et al., 2010). However, in this present study, we investigated on the antioxidant effect of methanolic extract of musa sapientum sucker (MEMSS) in indomethacin-induced ulceration in Wistar rats. From our results, we scored ulcer induction using indomethacin biochemical alterations which manifested as statistically increased significant $(\mathrm{p}<0.05)$ of serum, stomach, hepatic as well as renal marker enzymes. This corroborated with the earlier literature reports in rats (Yin et al., 2008; Adewoye et al., 2009). Possibly, these radicals promote lipid peroxidation and membrane damage by cross-linking proteins, lipids and nucleic acids (Del et al., 1980; Kumaraguruparan et al., 2002). Similarly, when compared to the effectiveness of omeprazole $(0.8 \mathrm{mg} / \mathrm{kg})$ as observed in this study, MEMSS significantly reduced the elevated liver and kidney aminotransferases following indomethacin intoxication in rats. Also, MEMSS when administered at graded doses $(5 \mathrm{mg} / \mathrm{kg}, 10 \mathrm{mg} / \mathrm{kg}$ and $20 \mathrm{mg} / \mathrm{kg})$ increased $(\mathrm{p}<0.05)$ stomach superoxide dismutase and catalase levels including liver and kidney superoxide dismutase levels $(\mathrm{p}<0.05)$. More so, both superoxide dismutase and catalase play an important role in the detoxification of superoxide anion and hydrogen peroxide respectively thereby protecting the cells against oxidative free radicals-induced damage (Kumaraguruparan et al., 2002). Oxygen radicals such as superoxide serve as an agent of oxygen toxicity. Excessive generation of metabolites of over synthesis of substances could increase oxidation which generate reactive oxygen radicals or play feedback interference to the efficiency of equilibrium system. For instance superoxide dismutase or reduced glutathione provide an important defence in free radical pathology (Fridovich, 1973; Butterfield \& McGraw, 1973). This is an indication of the suitability of MEMSS to ameliorate biochemical alterations that may be underlying ulcers formation. For instance, a $20 \mathrm{mg} / \mathrm{kg}$ of MEMSS as observed in our study increased liver and renal reduced glutathione in the treated rats. Thus, reduced glutathione (GSH) may play a central role in the defense against free radicals, peroxides and a wide range of xenobiotics and carcinogens.

\section{Conclusion}

Overall, we concluded therefore that methanolic extract of musa sapientum sucker (MEMSS) proffers antioxidant actions which may trigger chemopreventive benefits against indomethacin-induced ulceration in rats. However, our study provides basis for further histomorphological studies.

\section{Reference}

[1]. Adewoye E. O., Taiwo V.O., Olayioye F. A. Anti-oxidant and anti-hyperglycemic activities of Musa sapientum root extracts in alloxaninduced diabetic rats. Afr J Med Med Sci. 2009; 38, 109-117.

[2]. Agarwal P.K, Singh A, Gaurav K, Goel S, Khanna H.D \& Goel R.K, Evaluation of Wound healing activity of extracts of plantain Banana (Musa sapientum Var. Paradisiaca) in rats. Indian journal of experimental Biology, 47: 32-40, (2009).

[3]. Alisi C.S., Nwanyanwu C.E., Akujobi C.O., Ibegbulem C.O. Inhibition of dehydrogenase activity in pathogenic bacteria isolates by aqueous extracts of Musa paradisiaca (var. sapientum). Afr. J. Biotechnol. 2008; 7(12): 1821-1825.

[4]. Beutler E., O. Duron, and B. M. Kelly, "Improved method forthe determination of blood glutathione," The Journal of Laboratory and Clinical Medicine, vol. 61, pp. 882-888, 1963.

[5]. Del Maestro R E, Thaw H H, Bjork J, Planker M \& Artors K E, Free radicals as mediators of tissue injury, Acta Physiol Scand, 492 (1980) 43.

[6]. Eiserich J. P., M. Hristova, C. E. Cross et al., "Formation of nitric oxide-derived inflammatory oxidants by myeloperoxidase in neutrophils," Nature, vol. 391, no. 6665, pp. 393-397, 1998.

[7]. Fridovich I, The biology of oxygen radicals. The superoxide radical is an agent of oxygen toxicity; superoxide dismutase provide an important defence, Science, 201 (1978) 875.

[8]. Goel R.K., Sairam K. Anti-ulcer Drugs from Indigenous Sources with Emphasis on Musa sapientum, Tamrabhasma, Asparagus racemosus and Zingiber officinale. Indian J. Pharmacol. 2002; 34: 100-110.

[9]. Habig W. H., M. J. Pabst, and W. B. Jakoby, "Glutathione S transferases. The first enzymatic step in mercapturic acid formation," The Journal of Biological Chemistry, vol. 249, no. 22-25, pp. 7130-7139, 1974.

[10]. Jachak S.M., Saklani A. Challenges and opportunities in drug discovery from plants. Curr. Sci., 2007; 92(9): 1251-1257.

[11]. Jain D.L., Baheti A.M., Parakh S.R., Ingale S.P., Ingale P. L. Study of antacid and diuretic activity of ash and extracts of Musa sapientum L. fruit peel. Phcog. Mag. 2007; 3(10): 116-119.

[12]. Kumaraguruparan R, Subapriya R, Viswanathan P \& Nagini S, Tissue lipid peroxidation and antioxidant status in patients with adenocarcinoma of the breast, Clin Chim Acta, 325 (2002) 165.

[13]. Levine G., A Guide To SPSS For Analysis of Variance, Lawrence Erlbaum, Hillsdale, NJ, USA, 1991.

[14]. Lewis D.A, Fields W. N \& Shaw G. P, A natural flavonoid present in unripe plantain banana pulp (Musa sapientum L. var. paradisiaca) protects the gastric mucosa from aspirin-induced erosions. Journal of Ethnopharmacology, 65(3): 283-288, (1999).

[15]. Misra H. P. and I. Fridovich, "The role of superoxide anion in the autoxidation of epinephrine and a simple assay for superoxide dismutase," The Journal of Biological Chemistry, vol. 247, no. 10, pp. 3170-3175, 1972.

[16]. Newman D.J., Cragg G.M., Snader, K.M. Natural products as sources of new drugs over the period 1981-2002. J. Nat. Prod. 2003; 66(7): 1022-1037.

[17]. Pari L., Maheshwari U.J. Antihyperglycemic activity of Musa sapientum flowers: effect on lipid peroxidation in alloxan diabetic rats. Phytother. Res. 2000; 14:136-138.

[18]. Salau B. A. and Ajani E. O, (2012). Methanolic Extract of Musa Sapientum Sucker sucker improves lipid profiles in Alloxan Induced Diabetes Rats. Asian Journal of Biological Science 5 (6): 322 - 327 
[19]. Salau B. A, Ajani E. O, Akinlolu A. A, Ekor M. M, and Soladoye M. O, (2010). Methanolic Extract of Musa Sapientum Sucker Moderates Fasting Blood Glucose and Body Weight of Alloxan Induced Diabetes Rats. Asian J. EXP. BIOL.SCI, 1 (1): 30 - 35.

[20]. Sinha A. K., "Colorimetric assay of catalase," Analytical Biochemistry, vol. 47, no. 2, pp. 389-394, 1972.

[21]. Vijayakumar S., Presannakumar G., Vijayalakshmi N.R. Antioxidant activity of banana flavonoids. Fitoterapia 2008; 79: $279-282$.

[22]. Weight of Alloxan Induced Diabetic Rats. Asian J. Exp. Biol. Sci., 1(1): 30-35, (2010).

[23]. Yin X., Quan J., Kanazawa T. Banana Prevents Plasma Oxidative Stress in Healthy Individuals. Plant Foods Hum. Nutr. 2008; 63: $71-76$. 